\title{
PENENTUAN KADAR FLAVONOID DAN VITAMIN C DALAM UMBI BAWANG HUTAN (Eleutherine bulbosa (Mill) Urb) YANG BERASAL DARI DESA MATANTIMALI KABUPATEN SIGI
}

\section{Determination of Flavonoid and Vitamin C Levels on Onion Bulbs Forest (Eleutherine bulbosa (Mill) Urb) from Sigi Matantimali}

\author{
* Karmila, Minarni R. Jura dan Vanny M. A. Tiwow \\ Pendidikan Kimia/FKIP - Universitas Tadulako, Palu - Indonesia 94118 \\ Received 7 March 2018, Revised 9 April 2018, Accepted 8 May 2018
}

\begin{abstract}
This study aimed to determine flavonoids and vitamin $C$ levels contained in forest onion bulbs (Eleutherine bulbosa (Mill) Urb). Determination of the levels of flavonoids in forest onion bulbs extracted by maceration in etanol-HCl 1\%, while vitamin $C$ is extracted with $96 \%$ ethanol. Flavonoids and vitamin $C$ levels in samples of forest onion bulbs were determined using $U V$-Vis spectrophotometer. The result showed that the flavonoids levels obtained was as much as $13.4058 \mathrm{mg} / 100 \mathrm{~g}$, while vitamin C levels was as much as $31.678 \mathrm{mg} / 100 \mathrm{~g}$.
\end{abstract}

Keywords: Forest onions, flavonoids, vitamin C, method extraction maceration.

\section{Pendahuluan}

Indonesia terkenal dengan kekayaan alam yang memiliki jenis tumbuhan yang berkhasiat sebagai obat tradisional dan telah dikenal dan digunakan secara turun-temurun oleh masyarakat Indonesia. Pemanfaatan obat tradisional pada umumnya lebih diutamakan untuk menjaga kesehatan, meskipun pemanfaatannya ada pula ditujukan sebagai pengobatan suatu penyakit (Maryani \& Suharmiati, 2003).

Menurut catatan World Health Organization (WHO) pemanfaatan keanekaragaman hayati (bioprospecting) sangat besar sekali, diperkirakan hampir $80 \%$ dari umat manusia terutama di negara-negara sedang berkembang masih menggantungkan pada tumbuh-tumbuhan (ekstrak dan bahan bioaktif) sebagai bahan obat untuk menjaga kesehatannya (Chairul, dkk., 2003).

Popularitas tumbuhan obat atau herbal semakin meluas. Berbagai jenis produknya terus bermunculan seperti herba medicine (obat herbal). Sebagian masyarakat tidak menyadari bahwa sebagian besar produk herbal tersebut bahannya ada di sekeliling kita. Sekian banyak umbi yang berkhasiat obat, terdapat tujuh jenis umbi yang paling bermanfaat, diantaranya umbi bawang hutan, umbi bawang putih, umbi bawang merah, umbi bawang bombai, umbi sarang semut, umbi bidara upas, dan umbi keladi tikus (Prapti, 2013).

Salah satu jenis bawang yang akhir-akhir ini makin banyak beredar di pasaran, terutama kota Palu adalah bawang hutan. Bawang hutan

*Correspondence

Karmila

Program Studi Pendidikan Kimia, Fakultas Keguruan dan Ilmu Pendidikan, Universitas Tadulako

e-mail: karmilamila118@gmail.com

Published by Universitas Tadulako 2018
(Eleutherine bulbosa (Mill) Urb) merupakan suatu tanaman yang banyak digunakan sebagai obat tradisional dan antioksidan alami. Kulit umbi bawang hutan berwarna terang dan tidak berkecambah. Secara tradisional bawang hutan dimanfaatkan sebagai obat, menyembuhkan radang hati, radang sendi, radang tonsil dan radang pada teggorokan. Tinggi rendahnya kualitas berbagai tipe bawang ternyata ditentukan oleh senyawa utama yang terkandung didalamnya, yaitu senyawa golongan fenol dan flavonoid. Keduanya merupakan senyawa yang mempunyai khasiat sebagai antioksidan (Jerwati, 2012). Untuk itu dilakukan berbagai penelitian dan pengujian terhadap obat tradisional tersebut, sehingga penggunaan obat tradisional semakin rasional dan meningkatkan popularitasnya, disamping itu himbauan pengobatan kembali ke alam menempatkan obat tradisional lebih banyak digemari masyarakat. Hal ini terbukti dengan semakin banyaknya industri farmasi yang memproduksi obat tradisional untuk kebutuhan masyarakat (Maryani \& Suharmiati, 2003).

Salah satu kandungan pada bawang hutan ini juga adanya vitamin $\mathrm{C}$ yang merupakan sumber antioksidan. Sebagai donor elektron, vitamin C adalah antioksidan yang larut dalam air (Padayatty, dkk., 2003). Menurut Khomson (2010) vitamin C sebagai salah satu antioksidan alami secara luas dianjurkan dalam mengobati dan mentoksifikasi (mengurangi sifat racun). Menurut Suhartono, dkk., (2002), aktivitas radikal bebas tersebut dapat diredam dengan adanya antioksidan yang merupakan senyawa yang dapat menyumbangkan satu atau lebih elektron kepada radikal bebas. Vitamin C mudah diabsorbsi secara aktif dan mungkin pula secara difusi pada bagian atas usus halus lalu masuk keperedaran darah melalui vena porta. Rata-rata absorpsi adalah 90\% untuk konsumsi diantara $20 \mathrm{mg}$ dan $120 \mathrm{mg}$ sehari. 
Tubuh dapat menyimpan hingga $1500 \mathrm{mg}$ vitamin C, bila konsumsi mencapai $100 \mathrm{mg}$ sehari (Almatsier, 2001). Tiap individu memiliki kebutuhan vitamin $\mathrm{C}$ yang berbeda. Pada bayi diperkirakan sekitar $30 \mathrm{mg}$ per hari, pada anakanak sekitar $60 \mathrm{mg}$ per hari, pada usia pertumbuahan sekitar $75 \mathrm{mg}$ per hari, pada orang dewasa sekitar $90 \mathrm{mg}$ per hari, pada wanita hamil sekitar $100 \mathrm{mg}$ per hari, dan pada ibu menyusui sekitar $150 \mathrm{mg}$ per hari (Marsetyo \& Kartasapoetra, 1990).

Beberapa fungsi vitamin $\mathrm{C}$ yang sangat penting adalah sintesis kolagen, biosintesis kamitin, metabolism bistamine, sintesis neurotransmitter (neropinefrin) dan fungsi imun, serta meningkatkan kemampuan absorpsi zat besi nonheme, hidroksida kolesterol di mikroso hepatic agar dapat diekresikan dalam asam empedu, mereduksi metal yang toksik dan meningkatkan imunitas (Leveine, dkk., 1995).

Dalam umbi bawang hutan terkandung senyawa fitokimia yakni alkaloid, glikosida, flavonoid, fenolik, steroid dan zat tanin. Secara empiris bawang hutan sudah dipergunakan masyarakat lokal sebagai obat berbagai jenis penyakit seperti kanker payudara, penurun hipertensi, penyakit kencing manis (diabetes melitus), menurunkan kolesterol, obat bisul, kanker usus, mencegah stroke dan mengurangi sakit perut setelah melahirkan. Selain itu, daun tanaman ini juga dapat digunakan sebagai pelancar air susu ibu dan mencegah penyakit jantung, immunostimulant, antinflamasi, antitumor serta anti bleeding agent (Galingging, 2009).

Penelitian-penelitian mengenai kandungan flavonoid pada berbagai macam tanaman banyak dilakukan. Salah satunya yaitu pada tanaman Katu (Sauropus androgynus L) yang banyak digunakan sebagai bahan obat tradisional mengobati frambusia, anti diuretik, dan obat luar (Wijono \& Harsodjo, 2003). Ada juga penelitian flavonoid dari biji jinten hitam (Nigella sativa L.) dikatakan memiliki berbagai khasiat antara lain analgesik, antiinflamasi, antihistamin, antioksidan, antikanker, imunomodulator, antihipertensi dan antivirus (Qaliff, 2012).

Flavonoid merupakan salah satu senyawa kimia yang tergolong senyawa metabolit sekunder. Kemungkinan keberadaannya di dalam daun pada tumbuhan dipengaruhi oleh adanya proses fotosintesis, sehingga daun muda belum terlalu banyak mengandung flavonoid (Markam, 1998). Flavonoid adalah zat fenolik yang diisolasi dari berbagai tumbuhan vaskular, dengan lebih dari 8000 senyawa individu yang dikenal. Flavonoid bertindak sebagai antioksidan, antimikroba, fotoreseptor, attractor visual, makan repellants, dan untuk skrining cahaya. Banyak penelitian menunjukkan bahwa flavonoid menunjukkan aktivitas biologis, termasuk antiallergenic, antivirus, antiinflamasi, dan tindakan vasodilatasi. Namun, yang paling menarik telah dikhususkan untuk aktivitas antioksidan flavonoid, karena kemampuan mereka untuk mengurangi pembentukan radikal bebas. (Pietta, 2000).

Tulisan ini mendeskripsikan penentuan kadar flavonoid dan vitamin $\mathrm{C}$ dari umbi bawang hutan (Eleutherine bulbosa (Mill) Urb) yang berasal dari Desa Matantimali Kabupaten Sigi.

\section{Metode}

\section{Alat dan Bahan}

Alat yang diperlukan dalam penelitian meliputi: Erlenmeyer, pipet tetes, gelas ukur, mesin kocok agitasi, kertas saring, corong, spektrofotometer UV-Vis (Perkin Elmer Lamda 25), neraca digital (adventurer Ohaus), spatula, gelas kimia, tabung reaksi, cawan petri, labu ukur, Erlenmeyer, batang pengaduk, ayakan, dan blender.

Bahan-bahan yang digunakan dalam penelitian adalah umbi bawang hutan, larutan Etanol-HCl 1 $\%$ (Merck), Larutan buffer $\mathrm{pH} 1$ dan $\mathrm{pH} 4,5$ (Merck), aluminium foil, Vitamin C murni (Merck), larutan etanol 96\% (Merck).

\section{Preparasi sampel}

Sampel umbi bawang hutan $100 \mathrm{~g}$ dipisahkan dan dibersihkan dari bagian daun dan kulit luar bawang hutan. Selanjutnya umbi bawang hutan dikupas tipis-tipis, kemudian ditimbang dengan menggunakan neraca digital dan dikeringkan menggunakan oven selama 2 hari selanjutnya dihancurkan menggunakan blender kering sampai halus menghasilkan serbuk umbi bawang hutan dan akhirnya diekstraksi secara maserasi dengan pelarut etanol- $\mathrm{HCl} 1 \%$.

\section{Penentuan kadar flavonoid}

$5 \mathrm{~g}$ bubuk sampel ditambahkan larutan etanol$\mathrm{HCl} 1 \%$ dan dikocok campuran di atas mesin agitasi $250 \mathrm{rpm}$ selama 2 jam selanjutnya filtrat dimasukkan ke dalam 2 buah tabung reaksi. Pada setiap tabung dimasukan berturut-turut $5 \mathrm{~mL}$ larutan buffer $\mathrm{pH} 1$ dan tabung kedua dimasukan larutan $\mathrm{pH}$ 4,5 selanjutnya diukur absorbansi menggunakan spektrofotometer UV-Vis pada panjang gelombang berturut-turut $510 \mathrm{~nm}$ dan $700 \mathrm{~nm}$.

\section{Kadar vitamin $C$}

$27 \mathrm{mg}$ Vitamin C murni ditimbang, kemudian dilarutkan dalam labu ukur $25 \mathrm{~mL}$ menggunakan etanol $96 \%$ sebanyak $10 \mathrm{~mL}$. Selanjutnya diukur serapan larutan induk vitamin $\mathrm{C}$ pada panjang gelombang 200-400 nm untuk mengetahui panjang gelombang maksimum.

Larutan standar vitamin C dibuat seri konsentrasi $150 \mathrm{ppm}, 200 \mathrm{ppm}$, dan $250 \mathrm{ppm}$ dari larutan induk Vitamin C 1000 ppm kemudian diukur serapan larutan standar menggunakan spektrofotometer UV-Vis pada panjang gelombang $521 \mathrm{~nm}$.

\section{Penentuan kadar vitamin $C$}

Selanjutnya sampel umbi bawang hutan 500 mg diektraksi dengan menggunakan etanol $96 \%$ $25 \mathrm{~mL}$, perlakuan ini berturut-turut diulangi 
hingga semua vitamin $\mathrm{C}$ terekstrak (ekstrak tidak lagi berwarna). Selanjutnya filtrat yang diperoleh diukur serapannya menggunakan spektrofotometer UV-Vis pada panjang gelombang maksimum (jika serapan sampel melebihi serapan larutan standar, maka lakukan pengenceran.

\section{Hasil dan Pembahasan}

\section{Kadar flavonoid}

Penentuan kadar flavonoid pada umbi bawang hutan (Eleutherine bulbosa (Mill) Urb) dengan menggunakan metode ekstraksi cara maserasi. Proses ektraksi adalah proses dimana suatu senyawa yang diinginkan ditarik dengan menggunakan pelarut yang sama sesuai dengan sifat dari senyawa yang akan dipisahkan. Berdasarkan hasil analisis penelitian maka kadar flavonoid yang diperoleh pada sampel umbi bawang (Eleutherine bulbosa (Mill) Urb) yaitu sebesar $13,4058 \mathrm{mg} / 100 \mathrm{~g}$. Beberapa penelitian yang telah dilakukan Febrinda, dkk., (2013) kandungan flavonoid total dari sampel umbi bawang dayak dengan menggunakan pelarut air dan etanol diperoleh nilai sebesar $65,35 \pm 0,55 \mathrm{mg} / \mathrm{g}$. Menurut Setyaningrum (2010) kadar antosianin dalam 100 gram sampel kulit buah manggis dengan menggunakan pelarut aseton dengan variasi larutan $\mathrm{HCl} 1 \%$ diperoleh kadar sebesar $0,15 \mathrm{mg}$. Antosianin merupakan golongan senyawa flavonoid yang memiliki fungsi sebagai antioksidan alami.

\section{Penentuan kurva standar vitamin C}

Hasil pengukuran serapan larutan standar vitamin C dapat dilihat pada Tabel 1 .

Tabel 1. Hasil pengukuran serapan larutan standar vitamin C using UV-Vis $(\lambda=521 \mathrm{~nm})$

\begin{tabular}{cc}
\multicolumn{2}{c}{ vitamin C using UV-Vis $(\lambda=521 \mathrm{~nm})$} \\
\hline \multicolumn{2}{c}{ Kurva Standar vitamin C } \\
\hline Konsentrasi (ppm) & Absorbansi \\
150 & 0,1519 \\
200 & 0,3981 \\
250 & 0,6198 \\
\hline
\end{tabular}

diperoleh mendekati nilai 1,000 dimana terdapat korelasi yang positif antara vitamin $\mathrm{C}$ dengan serapan. Artinya peningkatan konsentrasi vitamin $\mathrm{C}$ akan mengakibatkan peningkatan nilai absorbansi yang terbaca pada spektrofotometer UV-Vis secara linier. Penggunaan pelarut etanol digunakan karena sifatnya yang universal yang dapat melarutkan senyawa yang bersifat polar dan bersifat nonpolar. Vitamin $\mathrm{C}$ memiliki banyak ikatan polar $\mathrm{O}-\mathrm{H}$ dan $\mathrm{C}-\mathrm{O}$ sehingga membuat vitamin $\mathrm{C}$ bersifat polar dan dapat terekstrak oleh pelarut etanol.

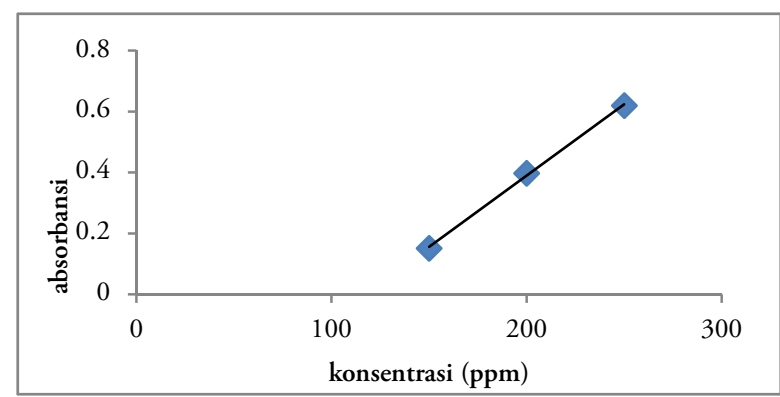

Gambar 1. Kurva standar hubungan antara konsentrasi vitamin $\mathrm{C}$ dengan absorbansi

\section{Kadar Vitamin C}

Hasil penelitian kadar vitamin C pada umbi bawang hutan (Eleutherine bulbosa (Mill) Urb) dapat dilihat pada Tabel 2.

Berdasarkan hasil penelitian maka kadar vitamin $C$ yang diperoleh pada sampel umbi bawang hutan sebesar 31,678 mg/100 g. Beberapa penelitian menunjukkan bahwa Karinda, dkk., (2013) kadar vitamin C dalam 50 g sampel mangga dodol dengan metode spektrofotometer UV_Vis diperoleh nilai sebesar $15,88 \mathrm{mg} / 100 \mathrm{~g}$. Menurut Putra (2011) kadar vitamin C pada bawang putih (Alium Sativum L) metode titrasi 2,6-diklorofenol indofenol diperoleh kadar vitamin C sebesar $27,45 \mathrm{mg} / 100 \mathrm{~g}$. Dari perbandingan ini maka kadar Vitamin C pada umbi bawang hutan tersebut tidak memiliki perbedaan cukup jauh

Tabel 2. Hasil analisis vitamin C pada umbi bawang hutan (Eleutherine bulbosa (Mill) Urb)

\begin{tabular}{ccccccc}
\hline Sampel & Absorbansi & $\begin{array}{c}\text { Bobot } \\
\text { sampel }(\mathrm{mg})\end{array}$ & $\begin{array}{c}\text { Volume } \\
(\mathrm{L})\end{array}$ & $\mathrm{Fp}$ & $\begin{array}{c}\text { Konsentrasi } \\
\text { Vit.C(ppm) }\end{array}$ & $\begin{array}{c}\text { Konsentrasi Vit.C } \\
(\mathrm{mg} / 100 \mathrm{~g} \text { bahan })\end{array}$ \\
\hline $\begin{array}{c}\text { Bawang } \\
\text { hutan }\end{array}$ & 0,46 & 500 & 0,02 & 25 & 253,42 & 31,67 \\
\hline
\end{tabular}

Berdasarkan Tabel 1 absorbansi terhadap standar vitamin C dapat dialirkan membentuk suatu kurva larutan standar untuk meluruskan kurva tersebut digunakan persamaan garis regresi linear. Hasil perhitungan dengan program exel, diperoleh persamaan regresi $Y=0,004 x-0,545$ dengan $\mathrm{R}^{2}=0,999$. Hubungan antara absorban dan konsentrasi larutan standar vitamin C ditunjukkan pada Gambar 1.

Berdasarkan pada Tabel 1 diperoleh persamaan linier dari standar vitamin $\mathrm{C}$ dengan menggunakan pelarut etanol $96 \%$ yaitu $\mathrm{y}=0,004 \mathrm{x}-0,545$ dengan nilai regresi linier $\left(\mathrm{R}^{2}\right)$ yaitu 0,999 . Rentang nilai pada daerah ini menunjukan daerah respon linier suatu validasi metode penetapan kadar senyawa dalam suatu analit. Nilai $r$ yang dengan jumlah kadar yang lainnya. Selain komposisi dari jenis bawang yang berbeda, ada beberapa faktor yang mempengaruhi yaitu waktu ekstraksi, $\mathrm{pH}$ dan temperatur ekstraksi. pH larutan ekstraksi berpengaruh terhadap kestabilan warna pigmen.

Vitamin $\mathrm{C}$ mudah teroksidasi karena senyawa mengandung gugus fungsi hidroksi $(\mathrm{OH})$ yang sangat reaktif dengan adanya oksidator gugus hidroksi akan teroksidasi menjadi gugus karbonil. Proses oksidasi akan terhambat bila vitamin C berada dalam keadaan suhu rendah (Harper, 1986). Secara umum reaksi oksidasi vitamin C adadua macam yaitu proses oksidasi spontan danproses oksidasi tidak spontan. Prosesoksidasi spontan adalah proses oksidasi yangterjadi tanpa 
menggunakan enzim ataukatalisator. Sedangkan proses oksidasi tidakspontan yaitu reaksi yang terjadi denganadanya penambahan enzim atau katalisator, misal enzim glutation. Enzim ini adalahsuatu tripeptida yang terdiri dari asamglutamat, sistein, dan glisin (Andarwulan \& Koswara, 1992)

Dalam keadaan kering vitamin C cukup stabil, tetapi dalam keadaan larut vitamin $\mathrm{C}$ mudah rusak karena bersentuhan dengan udara (oksidasi) terutama bila terkena panas. Vitamin C tidak stabil dalam larutan alkali, tetapi cukup stabil dalam larutan asam. Vitamin C dapat disintesis dari Dglukosa dan D-galaktosa dalam tumbuh-tumbuhan dan sebagian besar hewan (Almatsier, 2009).

\section{Kesimpulan}

Kadar flavonoid yang terkandung di dalam umbi bawang hutan (Eleutherine bulbosa (Mill) Urb) dengan larutan Etanol-HCl $1 \%$ adalah $13,4058 \mathrm{mg} / 100$ g. Sedangkan kadar Vitamin C yang terkandung di dalam umbi bawang hutan (Eleutherine bulbosa (Mill) Urb) dengan larutan etanol $96 \%$ adalah $31,678 \mathrm{mg} / 100 \mathrm{~g}$.

\section{Ucapan Terima Kasih}

Penulis mengucapkan terima kasih kepada pihak yang telah membantu penelitian ini, khususnya kepada laboran Laboratorium Penelitian Kimia Fakultas Matematika dan Ilmu pengetahuan Alam Universitas Tadulako Palu, Sulawesi Tengah atas bantuannya selama penulis melaksanakan penelitian.

\section{Referensi}

Almatsier, S. (2001). Prinsip dasar ilmu gizi. Jakarta: PT Gramedia Pustaka.

Andarwulan, N. \& Koswara. (1992). Kimia vitamin. Jakarta: Rajawali.

Chairul, S. M. C., Sumarny, R. \& Chairul. (2003). Aktivitas antioksidan ekstrak air daun tempuyung (sonchus arvensis l) secara in vitro. Majalah Farmasi Indonesia, 4(4), 208-215.

Febrinda, A. E., Made, A., Taufik, W. \& Nancy, Y. D. (2013). Kapasitas antioksidan dan inhibitor alfa glukosidase ekstrak umbi bawang dayak (Eleutherine palmifolia 1. merr). Teknologi dan Industri Pangan, 24(2), 1-7.

Galingging, R. Y. (2009). Bawang butan (eleutherine palmifolia l. (merr) sebagai tanaman obat multifungsi. Jakarta: Agromedia Pustaka.

Harper, L. J. (1986). Pangan gizi dan pertanian. Jakarta: Universitas Indonesia.

Ismayanti. (2013). Kajian kadar fenolat total dan aktivitas antioksidan jus kulit buah semangka (citrullus lanatus). Online Jurnal of Natural, 2(2), 100-110.

Jerwati. (2012). Uji aktifitas antioksidan ekstrak bawang hutan (eleutherine palmifolia l. (merr) dengan menggunakan metode DPPH dan formulasi sirup ekstrak bawang hutan. Skripsi, Palu: Sekolah Tinggi Ilmu Farmasi.

Karinda, M., Fatimawali \& Citraningtyas, G. (2013). Perbandingan hasil penetapan kadar vitamin $\mathrm{C}$ mangga dodol dengan menggunakan metode Spektrofotometer UVVis dan iodometri. Jurnal Ilmiah Farmasi, 2(1), $1-4$.

Khomson, A. (2010). Pangan dan gizi untuk kesehatan. Jakarta: PT Raja Grafindo Persada.

Levine, M., Dhariwal, K. R., Welch, R. W., Wang, Y. \& Park, J. B. (1995). Determination of optimal vitamin $\mathrm{C}$ requirements in humans. American Journal Clinical Nutrition, 2(1), 1-4.

Markam, K. R. (1998). Cara mengidentifikasi flavonoid. Bandung: Penerbit ITB.

Marsetyo, H. \& Kartasapoetra, G. (1990). Ilmu gizi. Jakarta: Rineka Cipta.

Maryani \& Suharmiati. (2003). Daun dewa sambung nyawa. Jakarta: Agromedia Pustaka.

Nugrahawati, A. Y. (2010). Pengaruh berbagai variasi subu dan warna kemasan terhadap stabilitas antosianin kulit manggis (garcinia mangostana l). Skripsi, Surakarta: Universitas Sebelas Maret.

Prapti, U. (2013). Umbi ajaib tumpas penyakit. Jakarta: Agromedia Pustaka.

Putra, A. A. (2011). Penetapan kadar vitamin C dari bawang putih (allium sativum L) secara titrasi 2,6-diklorofenol indofenol. Skripsi, Medan: Universitas Sumatera Utara.

Pietta, A. A. (2000). Flavonoids as antioxidants. Journal of Natural Products. 63(7), 1035-1042

Padayatty, S. J., Katz, A., Wang, Y., Eck, P., Kwon, O., \& Lee, J.-H. (2003). Vitamin C as an antioxidant: Evaluation of its role in disease prevention. Journal of the American College of Nutrition, 22(1), 18-35.

Qaliff, M. (2012). Isolasi dan identifikasi senyawa flavonoid dari biji jinten hitam (nigella sativa L). Skripsi, Bandung: Universitas Padjadjaran.

Setyaningrum, N. E. (2010). Efektifitas penggunaan jenis asam dalam proses ekstraksi pigmen antosianin kulit manggis (garcinia mangostana L) dengan penambahan aseton 60\%. Skripsi, Surakarta: Universitas Sebelas Maret.

Wijono, S. \& Hasodjo, S. (2013). Isolasi dan identifikasi flavonoid pada daun katu (souropus androgynus (l) merr). Makara, 7(2), 1-14. 